\title{
KEPEMIMPINAN CAMAT DALAM MENINGKATKAN DISIPLIN KERJA PEGAWAI DI KANTOR CAMAT SUNGAI TEBELIAN \\ KABUPATEN SINTANG
}

\section{Felix Semaun}

\author{
Fakultas Ilmu Sosial Dan Ilmu Politik Universitas Kapuas Sintang \\ Jalan Oevang Oeray 92 Sintang \\ Email : felix.unka@gmail.com
}

\begin{abstract}
Abstrac
The leadership of the sub-district head towards the improvement of the discipline of the civil servant has not been implemented maximally, which among others is still found disciplinary violations committed by employees regarding working hours, both coming hours and office hours are the forms of regulations often violated by employees so that the working time is less effective, in completing the task. that disciplinary violations committed by employees concerning the discipline of work, there are two factors as the cause, ie intentional factors, such as frequent late entry, often not absent, frequent home time, do not wear uniforms, neglect the instructions of superiors.
\end{abstract}

Keywords: Leadership, Employe Discipline.

\section{Abstrak \\ Kepemimpinan camat terhadap peningkatan disiplin kerja pegawai belum terlaksana secara maksimal, yang antara lain}

masih dtemukan pelanggaran disiplin yang dilakukan oleh pegawai mengenai jam kerja, baik jam datang maupun jam pulang kantor merupakan bentuk peraturan sering dilanggar oleh pegawai sehingga waktu kerja kurang efektif, dan terjadinya keterlambatan dalam menyelesaikan tugas. bahwa pelanggaran disiplin yang dilakukan oleh pegawai menyangkut disiplin kerja, ada dua faktor sebagai penyebab, yaitu faktor disengaja, seperti sering terlambat masuk, sering tidak tidak hadir, sering pulang belum saatnya, tidak memakai pakaian seragam, melalaikan instruksi atasan.

Kata Kunci: Kepemimpinan, Disiplin Kerja Pegawai.

\section{Latar Belakang}

Dalam rangka mencapai tujuan nasional perlu adanya disiplin dan kesadaran terhadap hukum dalam penyelenggaraan pemerintahan. Oleh karena itu, Pegawai Negeri Sipil yang merupakan aparatur negara 
sekaligus sebagai abdi masyarakat diperlukan peningkatan disiplin untuk meningkatkan profesionalisme dan tanggung jawab dalam bidangnya menuju aparatur pemerintah yang bersih dan berwibawa.

Sumber daya manusia adalah penggerak roda organisasi dalam mencapai dan mewujudkan tujuan dan sasaran yang telah ditetapkan organisasi. Sumber daya manusia sebagai asset non material dan non financial dalam organisasi mutlak sifatnya. Oleh karena itu, sumber daya manusia dapat merupakan asset utama organisasi, jika produktivitas sumber daya manusianya tinggi.

Pentingnya pemimpin dalam meningkatkan disiplin kerja pegawai, maka pemerintah mengeluarkan peraturan dengan maksud untuk memperbaiki dan mendidik para pegawai untuk mentaati segala peraturan perundang-undangan dan peraturan kedinasan yang berlaku agar dapat memenuhi tujuan lembaga yaitu melaksanakan tugas dengan penuh tanggung jawab dan dapat memberikan pelayanan kepada masyarakat dengan sebaikbaiknya.

Undang-Undang Nomor 43 tahun 1999 tentang Pokok-pokok Kepegawaian pasal 12 ayat 2 menyatakan bahwa: Untuk mewujudkan penyelenggaraan tugas pemerintahan dan pembangunan diperlukan Pegawai Negeri Sipil yang profesional, bertanggung jawab, jujur, dan adil melalui pembinaan yang dilaksanakan berdasarkan system prestasi dan system karier yang dititikberatkan pada system prestasi kerja. Pentingya disiplin kerja yang sudah diatur dalam peraturan pemerintah dengan maksud untuk memperbaiki dan mendidik para pegawai untuk mentaati segala peraturan perundang-undangan dan peraturan kedinasan yang berlaku.

\section{Pembahasan}

\section{A. Gambaran Umum Lokasi Penelitian}

Kecamatam Sungai Tebelian merupakan salah satu dari empat belas kecamatan di wilayah Kabupaten Sintang. Kecamatan ini memiliki luas $543.30 \mathrm{~km}^{2}$ $(2,43 \%)$ dari luas Kabupaten Sintang. Batas wilayah kecamatan ini meliputi sebelah utara berbatasandengan Kecamatan Sintang,sebelah Selatan berbatasan dengan Kabupaten Melawi atau Kecamatan Belimbing, sebelah Timur berbatasan dengan Kecamatan Dedai serta sebelah Barat berbatasan dengan Kecamatan Tempunak. Kecamatan Sungai Tebelian merupakan salah satu kecamatan yang dilalui jalan Propinsi yang menghubungkan Kota Sintang dengan Pontianak, juga di kecamatan ini dilalui oleh Sungai Kapuas dan Sungai Tebelian.

$$
\text { Pemerintah Kecamatan Sungai }
$$

Tebelian dalam menjalankan tugas didukung 
oleh 36 (tiga puluh enam) orang pegawai yang terdiri dari 29 (dua puluh sembilan) orang lakilaki dan 16 (enam belas) orang perempuan. Selain itu pegawai yang melaksanakan tugas juga didasarkan kepada berbagai kualifikasi pendidikan yang berbeda-beda. Berikut dapat dilihat tabel data pegawai Kantor Camat Sungai Tebelian menurut Tingkat Pendidikan.

Tabel 4.3. Data Pegawai Kantor Camat Kecamatan Sungai Tebelian Menurut Tingkat Pendidikan.

$\begin{array}{clcc}\text { No } & \text { Tingkat Pendidikan } & \text { Jumlah } & \text { Persentase } \\ 1 & \text { Sekolah Dasar } & 3 & 9,09 \\ 2 & \text { SLTP } & 3 & 4,54 \\ 3 & \text { SLTA } & 24 & 54,54 \\ 4 & \text { D.III/Sarmud } & 1 & 9,09 \\ 5 & \text { Sarjana / S.1 } & 4 & 18,18 \\ 6 & \text { Pasca Sarjana/S.2 } & 1 & 4,54 \\ & \quad \text { Jumlah } & 36 & 100\end{array}$

Sumber: Data Kantor Camat Sungai Tebelian, Tahun 2014.

Berdasarkan table tersebut diatas bahwa sumberdaya aparatur di Kantor Kecamatan Sungai Tebelian sangat minim dimana mayoritas adalah tamatan Sekolah Menengah Atas (24 orang pegawai) sementara untuk lulusan sarjana (D3, S1, S2) sangat minim (6 orang pegawai).

Susunan Organisasi dan Tata Kerja (SOTK) Pemerintah Kecamatan yang terbaru tersebut di atas, terlihat lebih efisien dengan jumlah formasi jabatan struktural yang lebih sedikit/ramping jika dibandingkan dengan struktur organisasi Pemerintah Kecamatan sebelumnya. Maksud dan tujuan dari Peraturan Pemerintah dan Perda tersebut adalah positif yaitu memberikan penghargaan kepada organisasi Pemerintahan Kecamatan melalui peningkatan eseloneringnya yang sudah barang tentu membawa implikasi pada peningkatan kesejahteraan dan kewibawaan pemerintahan kecamatan.

Mengacu kepada peraturan daerah tersebut, pemerintah Kecamatan Sungai Tebelian memiliki peta jabatan Pegawai Pemerintah Kecamatan Sungai Tebelian secara terperinci dapat digambarkan pada bagan berikut ini:

1. Kedudukan

a. Kecamatan merupakan perangkat daerah kabupaten/ kota atau Kotamadya/Kabupaten Administrasi di Propinsi yang mempunyai wilayah kerja tertentu, dan dipimpin oleh Camat.

b. Camat sebagaimana dimaksud dalamayat(1)berkedudukansebagai koordinator penyelenggaraan pemerintahan di wilayah kerjanya, berada di bawah dan bertanggung jawab kepada Bupati/walikota atau walikotamadya/Bupati administrasi di Propinsi melalui Sekretaris Daerah Kabupaten/ kota atau Kotamadya/Kabupaten Administrasi.

2. Tugas dan Fungsi

a. Camat mempunyai tugas dan fungsi melaksanakan 
kewenangan pemerintahan yang dilimpahkan oleh Bupati/Walikota atau Walikotamadya/Bupati Administrasi di Propinsi, sesuai karakteristik wilayah, kebutuhan daerah dan tugas pemerintahan lainnya berdasarkan peraturan perundang-undangan.

b. Pelimpahan kewenangan pemerintah sebagaimana dimaksud pada ayat (1) berpedoman pada Lampiran I Keputusan ini.

c. Sebagaimana tugas camat sebagaimana dimaksud dalam ayat (1) dan ayat (1) dan ayat (2) dapat dilimpahkan kepada Lurah.

Dalam melaksanakan tugasnya, camat, sekretaris, para kepala seksi dan kelompok jabatan fungsional wajib menerapkan prinsip koordinasi, integrasi dan sinkronisasi baik dalam lingkungan masing-masing maupun antar satuan organisasi Kecamatan sesuai dengan tugas pokok masing-masing. Setiap pimpinan satuan organisasi wajib mengawasi bawahan masing-masing dan bila terjadi penyimpangan agar mengambil langkahlangkah yang diperlukan sesuai dengan peraturan perundang-undangan.

Setiap pimpinan satuan organisasi Kecamatan bertanggungjawab memimpin, mengkoordinasikan bawahannya masingmasing dan memberikan bimbingan serta petunjuk bagi pelaksanaan tugas bawahan. Setiap pimpinan satuan organisasi wajib mengikuti dan mematuhi petunjuk dan bertanggungjawab kepada atasan masing- masing serta menyampaikan laporan berkala maupun seaktu-waktu sesuai kebutuhan.

\section{B. Kepemimpinan Camat Terhadap Pegawai di Kantor Camat Sungai Tebelian}

Berdasarkan informasi yang diperoleh dari informan Camat Sungai Tebelian melalui wawancara menunjukkan bahwa "menyatakan setiap pegawai diwajibkan oleh atasan mentaati peraturan yang berlaku di Kantor Camat Sungai Tebelian Kabupaten Sintang".pelanggaran terhadap peraturan yang sudah diwajibkan, meskipun frekuensinya jarang (kadang-kadang). Peraturan yang pernah dilanggar berkaitan dengan peraturan kedinasan yang ada hubungannya dengan pelaksanaan tugas pokok sehari-hari. Selanjutnya untuk mengetahui bentuk pelanggaran yang pernah dilakukan oleh pegawai mengenai jam kerja, baik jam datang maupun jam pulang kantor merupakan bentuk peraturan sering dilanggar oleh sebagian besar informan. Sedangkan sebagian kecilinforman pernah melanggar peraturan mengenai penggunaan waktu kerja kurang efektif, sehingga sering terjadinya keterlambatan dalam menyelesaikan tugas. Di samping itu ada sebagian informan yang menyatakan tidak pernah melanggar peraturan, sehingga mereka tidak ada pernyataan mengenai bentuk peraturan yang dilanggar". 
Berdasarkan hal tersebut diatas bahwa pelanggaran yang dilakukan oleh pegawai menyangkut disiplin kerja, ada dua faktor sebagai penyebab, yaitu faktor disengaja, seperti sering terlambat masuk, sering tidak tidak hadir, sering pulang belum saatnya, tidak memakai pakaian seragam, melalaikan instruksi atasan. Sedangkan faktor tidak sengaja seperti terjadinya kecelakaan.

Untuk mengetahui lebih jelas mengenai tindakan yang diberikan oleh atasan kepada bawahannya yang tidak mentaati peraturan yang berlaku, hasil wawancara Kasi Pemerintahan dan Kasi Trantib kantor Camat Sungai Tebelian ini dapat diketahui melalui prenyataan informn bahwa tindakan yang diberikan oleh atasan kepada pegawai yang melakukan pelanggaran disiplin kerja, terlihat dari tingkat kesalahan yang dilakukan oleh pegawai. Hal tersebut berdasarkan data bahwa sebagian besar informan menyatakan tindakan yang sering dilakukan adalah berupa peringatan ringan, yaitu peringatan dalam bentukpembinaan, bimbingan dan pengarahan, dengan maksud untuk memberikan atau menimbulkan kesadaran pegawai yang tidak mentaati peraturan disiplin. Namun ada juga informan yang menyatakan diberikan hukuman, hal tersebut dilihat dari tingkat kesalahan yang dilakukan.

Selanjutnya untuk mengetahui bentuk bimbingan yang pernah diberikan oleh pimpinan mengenai disiplin kerja, menurut hasil wawancara dengan Sekretaris Kecamatan Sungai Tebelian bahwa sebagian besar informan menyatakan bentuk bimbingan yang pernah diberikan adalah melalui pendidikan dan latihan terutama mengenai pemahaman terhadap peraturan pemerintah No.30 tahun 1980, tentang kewajiban pegawai negeri sipil dan larangan serta sanksi bagi pegawai negeri sipil yang melanggar peraturan tersebut, seperti ketaatan terhadap jam kerja, mekakai pakaian seragam sesuai dengan hari yang sudah ditentukan, mantaati setiap perintah dari atasan dan lain-lain.

Selanjutnya untuk mengetahui tanggapan informan mengenai pemberian bimbingan dari pimpinan Kantor Camat Sungai Tebelian menurut hasil wawancara Kasi Pemerintahan dalam penelitian ini diketahui bahwa pelaksanaan bimbingan disiplin kerja dinyatakan oleh sebagian besar informan belum dilakukan dengan serius, karena pimpinan belum sepenuhnya melaksanakan peraturan yang berlaku, seperti kurang tegasnya memberikan sanksi secara adil kepada pegawai yang melanggar peraturan, belum dpat menumbuhkan dan memelihara iklim kerja yang kondusif bagi inovasi dan kreativitas bawahan".

Berdasarkan hasil pengamatan penulis 
di lapangan, menunjukkan bahwa pola pembinaan disiplin kerja yang dilakukan di Kantor Camat Sungai Tebelian Kabupaten Sintang masih berorientasi kepada pola kepemimpinanotoritere,sehinggamenimbulkn akses yang kurang baik. Salah satu contoh, bawahan dalam mentaati peraturan bukan dilandasi oleh kesadaran, melainkan adanya rasa takut akan memperoleh hukuman jika melanggar. Seperti dalam pelaksanaan tugas, apabila ada pimpinan mereka rajin bekerja dan apabila tidak ada pimpinan mereka selalu menggunakan waktu tersebut untuk bercanda, tanpa memikirkan beban tugas yang menjadi tanggungjawabnya.

Dengan demikian pelaksanaan pembinaan dari atasan kepada bawahan tidak hanya berdasarkan pemberian bimbingan semata-mata, namun yang perlu menjadi perhatian adalah adanya kesadaran atau keinsyafan dari pegawai itu sendiri terhadap peraturan-peraturan yang berlaku dalam organisasi yang bersangkutan, meskipun bukan berarti kesadaran merupakan satusatunya faktor pokok dalam menegakkan disiplin.

\section{Disiplin Kerja Pegawai di Kantor Camat Sungai Tebelian}

Berdasarkan informasi yang diperoleh dari informan camat sebagi subjek dalam penelitian ini menyatakan bahwa ketaatan pegawai negeri di Kantor Kecamatan Sungai Tebelian terhadap pekerjaannya sama halnya ketaatannya kepada ideology negara/ pemerintah, kebijaksanaan pemerintah baik yang menyangkut kepentingan pegawai negeri sipil maupun kepentingan umum serta taat kepada atasan/pimpinan berdasarkan ketentuan yang berlaku dan mentaati setiap perintah dinas. Berdasarkan hal tersebut diatas informan Camat Sungai Tebelian juga memberikan informasi, bahwa ketertiban atau ketaatan dalam pelaksanaan tugas dapat diketahui dari ketertiban pegaai dalam melaksanakan tugas sesuai dengan kewenangannya dalam memberikan pelayanan, dalam memberikan sikap, bertutur kata dan berprilaku dalam kantor, serta menggunakan peralatan kantor.

Selanjutnya untuk mengetahui pertanyaan informan mengenai pelaksanaan setiap perintah yang diberikan oleh pimpinan, menurut Sekcam Sungai Tebelian dalam penelitian ini menyatakan bahwa sebagian besar informan menyatakan melaksanakan perintah atasan, terkadang dilaksanakan dan terkadang tidak dilaksanakan, misalnya pekerjaan yang dibebankan selalu tidak tepat waktu yang ditentukan, karena waktu kerja tidak sepenuhnya digunakan untuk bekerja, melainkan untuk bercanda dengan teman 
sekerja.

Untuk mengetahui bentuk perintah dari pimpinan, sehingga informan wajib melaksanakannya, menurut Kasi pemerintahan maupun Kasi Trantib Kecamatan Kantor Camat Sungai Tebelian dalam penelitian ini menyatakan bahwa diketahui bahwa metaati ketentuan yang menyangkut masalah kedinasan dan melaksanakan setiap perintah atau instruksi merupakan pernyataan dari sebagian besar informan tentang masalah perintah yang diberikan oleh atasan, Mengenai masalah kedinasan menyangkut masalah tugas pokok yang sudah menjadi kewajiban dari seorang pegawai sedangkan masalah perintah merupakan wewenang atasan dan juga merupakan suatu kewajibanyang harus dilaksanakan, karena pimpinan atau atasan merupakan penanggung jawab organisasi secara keseluruhan. Hal tersebut di atas sesuai dengan pernyataan dari seluruh informan yaitu dasar pegawai melaksanakan tugas adalah merupakan suatu kewajiban yang harus dilaksanakan sesuai dengan peraturan yang berlaku.

Selanjutnya untuk mengetahui kesalahan yang dilakukan oleh informan dalam melaksanakan tugas dalam penelitian ini baik camat maupun kepala Badan Kepegawaian Daerah Kabupaten Sintang menjelaskan bahwa informan menyatakan pernah melakukan kesalahan dalam melaksanakan tugas, namun frekuensi kesalahannya tergolong rendah (tidak terlalu sering) dan kesalahan yang dilakukan kadang kala diluar kemampuan pegawai, seperti sulitnya mempormulasikan instruksi dari atasan, sehubungan tugas yang diterima sebelumnya tidak ada petunjuk sehingga mengganggu kecepatan waktu penyelesaian. Hal tersebut dinyatakan oleh sebagian besar informan”.

Selanjutnya untuk mengetahui bentuk kesalahan yang pernah dan sering dilakukan oleh informan a menurut Sekcam di Kantor Kecamatan Sungai Tebelian dalam penelitian ini menjelaskan bahwa penyelesaian tugas tidak tepat waktu, karena penggunaan waktu dalam bekerja kurang efektif, sehingga sering menimbulkan keterlambatan dalam memberikan laporan hail kerja. Sedangkan bentuk kesalahan lain yang dilakukan oleh informan adalah pekerjan yang diselesaikan tidak sesuai dengan instruksi dari atasan, karena setiap tugas yang dilimpahkan oleh atasan jarang diberikan petunjuk atau pengarahan terlebih dahulu, sehingga bawahan sebagai pelaksanaan sulit untuk menafsirkan tugas tersebut dan akhirnya tugas yang dilaksanakan tidak sesuai dengan keinginan atasan.

Berdasarkan hasil pengamatan penulis di lapangan, dapat diketahui bahwa timbulnya 
kesalahan pegawai (bawahan) dalam melaksanakan tugas disebabkan kurangnya koordinasi antara atasan dengan bawahan di dalam memberikan perintah. Di satu sisi atasan dalam memberikan perintah tidak disertai dengan petunjuk yang jelas atau pengarahan terlebih dahulu dan di sisi lain kurang adanya inisiatif dari bawahan terhadap perintah yang diterima (asal menerima perintah saja), seperti mengkonsultasikan perintah yang dianggap kurang dipahami.

Untuk lebih jelasnya mengetahui tindakan hukum disiplin yang berlaku, melalui pernyataan Sekcam maupun Kasi di Kantor Kecamatan Sungai Tebelian Kabupaten Sintang dalam Penelitian ini menyatakan bahwa sebagian besar informan menyatakan tindakan hukuman disiplin yang berlaku sesuai dengan Undang-Undang No. 30 Tahun 1980 adalah hukuman disiplin ringan, sedang dan berat. Hal tersebut merupakan suatu ketentuan dengan menggolongkan masing-masing jenis hukuman disiplin sesuai dengan pelanggaran disiplin yang dilakukan, dimulai dari teguran sampai dengan pemberian sanksi administrasi oleh Camat sebagai unsur pimpinan".

Untuk mengetahui tata cara penjatuhan hukuman disiplin di Kantor Camat Sungai Tebelian Kabupaten Sintang dapat diketahui melalui hasil wawancara dengan Kasi Pemerintahan di Kantor Kecamatan Sungai
Tebelian dalam penelitian ini menyatakan bahwa sebagian besar informan menyatakan tata cara penjatuhan hukum disiplin adalah berdasarkan tingkat kesalahan yang dilakukan oleh informan (bawahan), apabila kesalahan yang dilakukan ringan, maka hukuman yang diperoleh atau diberikan atasan berupa teguran, baik secara lisan maupun tertulis. Contohnya jarang masuk kantor pada jam yang sudah ditentukan, tidak menggunakan pakaian seragam yang sudah ditetapkan, penggunaan waktu kerja tidak pada tempatnya dan lain-lain".

Kemudian seluruh informan dari hasil wawancara menyatakan bahwa atasan dalam melaksanakan hukuman disiplin belum sepenuhnya mengacu atau berpedoman kepada peraturan Pemerintah Nomor 30 Tahun 1980 yang telah menetapkan kewajiban dan larangan bagi pegawai negeri sipil serta sanksi bagi setiap pelanggaran larangan yang sudah ditetapkan.

\section{Simpulan}

Kepemimpinan camat dalam meningkatkan disiplin menunjukkan masih belum optimal, karena pelaksanaan kepemimpinan camat khususnya dalam pembinaan disiplin berupa bimbingan belum dilakukan secara kontinyu. Disiplin kerja pegawai dalam melaksanakan tugas terlihat 
masih belum optimal, karena belum seluruh pegawai (bawahan) yang melaksanakan perintah dari atasan dan belum optimalnya pelaksanaan tugas kedinasan dengan sebaikbaiknya serta dengan penuh pengabdian dan kesaadaran akan tanggungjawab dalam penyelesaian tugas yang tidak tepat waktu sesuai dengan ketentuan yang berlaku. Pengaruh Hubungan kepemimpimpinan camat terhadap peningkatan disiplin kerja pegawai di Kantor Camat Sungai Tebelian Kbupaten Sintang menunjukan hubungan yang kurang maksimal sehingga upaya merealisasikan tugas-tugas pemerintahan dalam pelayanan administrasi publik belum dapat diwujudkan dengan baik.

saranpenelitianyaituCamatmemahami berbagai faktor yang terkait dengan disiplin kerja seperti faktor kepribadian dan faktor lingkungan serta faktor-faktor lain dalam upaya merealisasikan disiplin kerja pegawai yang baik.Pembinaan disiplin kerja pegawai dapat dilakukan dalam dua cara, yaitu pertama melakukan bimbingan secara terus menerus melalui pemberian contoh atau ketauladanan, ke dua indoktrinasi (pemaksaan terhadap peraturan), dalam upaya untuk mengarahkan pegawai agar dapat melaksanakan tugas sesuai dengan ketentuan yang berlaku.

\section{DAFTAR PUSTAKA}

Azrita, Magdalena, 1999. Program Pemberdayaan Masyarakat Melalui LSM Pedesaan. Tesis.

Barry, Cushway, 2002. Human Resource Management. Edisi Bahasa Indonesia (Jilid 1 dan 2), Terjemahan Drs. Bunyamin Molan, Penerbit PT. Prenhallindo, Jakarta.

Brown, Rob, 1997. Perfect Empowerment Pemberdayaan Yang Tepat. PT. Elex Media Komputeria dan Kelompok Gramedia, Jakarta.

Burhannudin A. Tayibnapis, 1994. Administrasi Kepegawaian. Satuan Tinjauan Analitik.

Darwin, Muhadjir, 1999. Birokrasi Indonesia dan Pengembangan Aparatur. Ghalia Indonesia, Jakarta.

David Clutterbuck, Susan Kernaghan, 2003. The Power of Empowerment. Penerbit PT. Bhuana Ilmu Populer.

Hani, T. Handoko, 2001. Manajemen Personalia dan Sumber Daya Manusia. Edisi Kedua, Penerbit BPFE, Yogyakarta.

Henry, Sunanora, 1994. Manajemen Sumber Daya Manusia. Penerbit STIE YKPN, Yogyakarta.

Kumorotomo, Wahyudi, 1999. Etika Administrasi Negara. PT. Raja Grafindo Persada, Jakarta.

Miadmojo, Sudibyo, 1991. Membudayakan Disiplin di Kalangan Aparatur Pemerintahan. Gunung Agung, Jakarta.

Milkovich, George T. and Boudreaus, John W, 1991. Human Resource Management. Eigth Edition, Irwin Home Wood, Boston.

Musanef, 1990. Manajemen Kepegawaian di Indonesia. Gunung Agung, Jakarta.

Nitisemito, Alex, S, 1991. Manajemen Personalia. Ghalia Indonesia, 
Jakarta.

Notoatmodjo, Soekidjo, 1998. Pengembangan Sumber Daya Manusia. PT. Renika Cipta, Jakarta.

Oemar, Hamalik, 2000. Manajemen Pelatihan Ketenagakerjaan Pendekatan Perpadu. Bumi Aksara, Jakarta.

Pace, Wayne dan Don F. Faules, 2002. Komunikasi Organisasi, Strategi Meningkatkan Kinerja Perusahaan. Penerbit PT. Remaja Rosdakarya, Bandung.

Peraturan Pemerintah Nomor 100 Tahun 2000 dan diubah Peraturan Pemerintah Nomor 13 Tahun 2002 Tentang Pengangkatan Pegawai Negeri Sipil Dalam Jabatan Struktural.

Sedarmayanti, 2003. Good Governance Dalam Rangka Otonomi Daerah. Penerbit Mandor Maju, Bandung.

Sinaga, Anggiat M., 2001. Pemberdayaan Sumber Daya Manusia. Lembaga Administrasi Negara, Republik Indonesia.

Singarimbun, Masri dan Effendi Sofian, 1987. Metode Penelitian Survey. Cetakan Kedua, PT. Pustaka LP3S Indonesia, Jakarta.

Sudarmo, Gito dan Nyoman Sudita, 1997. Prilaku Keorganisasian. Edisi Pertama, Penerbit BPFE, Yogyakarta.

Thoha, Mitha, 1998. Prilaku Organisasi. Penerbit: CV. Rajawali, Jakarta.

Thoha, Mitha, Agus Dharma, 1998. Menyoal Birokrasi Publik, Kumpulan Makalah Pada Seminar Good Governance Dalam Reformasi Hukum Oleh International Center for Environmental Law. Agustus, 1998.

Tjokrowinoto, Moeljanto, 1999. Reorientasi Birokrasi Publik dan Era Globalisasi. Balai Pustaka, Jakarta.

Undang-undang Nomor 43 Tahun 1999. Tentang Perubahan UU No. 8 Tahun 1974 Tentang Pokok-pokok Kepegawaian. Penerbit Sinar
Usman, Marzuki, 1997. Manajemen Pembangunan. Gajah Mada University Press, Gajah Mada University Press, Yogyakarta.

Wahyudi, Kumorotomo, 1999. Etika Administrasi Negara. Raja Grafindo Persada, Jakarta.

Widowati, Mustika, 1998. Karier Lentur dan Model Pengelolaan Karier Masa Depan. Majalah Usahawan No. 02, Th XXVII, Pebruari. 